\title{
The Psalms' Ancient Musicality, Later Musical Reception and Bono's Psalmic Spirituality ${ }^{1}$
}

\author{
CHRISTO LOMBAARD (UNISA)
}

"It doesn't really matter what you heard: the holy or the broken 'Hallelujah",

- Leonard Cohen

\begin{abstract}
The link between the biblical Psalms and musicality is explored in this contribution. The interpretative engagement with texts as much as with music is indicated en route to taking a position on whether an authentic, accurate rendition of the ancient musicality of the Psalms can be recouped. Some instances of reception of the Psalms in classical, rock and electronic music genres are given, with greater attention devoted to influential rock star Bono's reflection on the role of Psalms and other music in shaping spirituality.
\end{abstract}

KEYWORDS: Psalms, musicality, spirituality, Bono

\section{A PSALMS PLAYED}

The interpretation of music, like the interpretation of texts - at which exegetes excel - is no simple matter. In both cases philosophical hermeneutics ${ }^{2}$ apply equally, with the concomitant practice of interpretative acts that overlap substantially. When textuality and musicality are combined, an even more involved matrix of interpretative possibilities arise. This is the case with the Psalms in the Hebrew Bible too. Although the same argument could be made for any lyrical text in the Bible, as much as for any in non-canonised literatures from

* Article submitted: 2019/07/12; peer reviewed: 2019/07/17; accepted: 2019/07/22. Christo Lombaard, "The Psalms' Ancient Musicality, Later Musical Reception and Bono's Psalmic Spirituality," OTE 32 no. 2 (2019): 764-780. DOI: https://doi.org/ 10.17159/2312-3621/2019/v32n2a25.

1 The nascence of this contribution lies in an invited guest lecture at the Lutheran School of Theology in Aarhus, Denmark, in May 2016. Here substantially expanded and altered, it is an honour for me to dedicate this publication to colleague Phil Botha. Both in his person and in his scholarship, he has always been someone I have admired, for all the positive qualities that he brings so seemingly naturally, such as evenmindedness and a carefully considered thoroughness. We are all enriched by him, and I am grateful for the influence he has had on me and on us as his colleagues.

2 Cf. Anthony Thiselton, New Horizons in Hermeneutics (Grand Rapids, MI: Zondervan, 1992). 
the ancient world, no parallel collection to the 150 Psalms exists which provides for such an extensive yet still boundaried corpus of poetic-musical texts.

The practical interpretation of the musicality of any given lyrical text, biblical or not, is a given: there is no way to perform music that is not a rendering. Every repetition of a musical piece is in a sense a new creation; even the nonmusical rendition of a lyrical text is a rendering of the piece, albeit in such instances without its intended melodic and rhythmic aspects. The latter kind of non-musical engagement is namely the case with most readings of the Psalms, ${ }^{3}$ where they are employed for liturgical, study or edifying purposes, namely as texts in the first instance, with (perhaps, though not always) the underlying sense that music would have accompanied these words, yet which sense finds no explicit expression in the way the text is now understood.

This, not for a moment to assume - two easy errors to commit - that in all or even in most instances of the Psalms there had been an original version ${ }^{4}$ or that such a putative version had indeed been laid down in the canonical text (contra the kind of view of text promoted by Childs, ${ }^{5}$ earlier academically more influential than at present, but still widely subscribed to, implicitly, in especially church circles). In the Psalter - without falling prey to such erroneous assumptions - we can at best assume to have versions of lyrical religious poetry, included in the canonised ${ }^{6}$ collection for any number of reasons. Once a text/song had been canonised, and has through such a process in a sense been afforded greater stability in form, the dynamism inherent to a lyrical text such as a Psalm is such that it may best be described as uneven. In editorial work, in understanding and in musical performance, variance remains a natural characteristic of such a text/song. The lyrical component of the text would, however, exhibit greater stability over time than its musical component - a dynamic which will be observable only as the Psalm is performed as music. Each performance of a song is namely a new way of "giving life" again to the Psalm, in a different genre of communication than exegetes of texts may attend to. In church life, with the text of the Psalms now "translated' into a wholly different cultural-musical milieu, this can be seen quite clearly when a Psalm is sung

3 For historical reviews of the interpretation of the individual Psalms, cf., e.g., the project by Susan Gillingham, including Psalms through the Centuries (Volume Two, Oxford: Wiley Blackwell, 2018).

4 This parallels directly what had written on textual criticism in general by e.g. Ferdinand Deist, Witnesses to the Old Testament (Literature of the Old Testament 5, Pretoria: NG Kerkboekhandel, 1988).

5 Brevard Childs, Old Testament Theology in a Canonical Context (London: SCM, 1985).

6 The canonization process had, naturally, been an extended activity rather than a single decision. 
during a worship service: to employ for a moment the language of Semiotics, ${ }^{7}$ the signs of the text - its components of lyrical and musical notation communicate in a fully different modality when they are performed to when they lie on paper. This performative transformation remains the case, however, irrespective of the musical genre or the culture and age in which a Psalm is performed.

\section{B PSALMS REPLAYED}

Comparatively little is known about the ancient Semitic musicality of the Psalms. Some analytical remarks on psalmic poetry and musicality are possible, and valuable ${ }^{8}$ but precisely what a Psalm "performed" in practice would have sounded like and would have been experienced as, remain to a substantial extent obscure to us. This is as much because we are not in possession of musical notation in formats as has been refined in the modern world, as it is due to the nature of music in cultures other than currently dominant cultures. These cultures are so dissimilar, that understanding music as practised in such contexts would well serve as an example of the difficulties involved with intercultural communication 9 . Important as the poetic textual qualities of the Psalter are, it must be admitted that, had the musicality of these ancient songs ${ }^{10}$ been as well-

7 The ideas of Charles Peirce and Ferdinand de Saussure on semiotics had been influential among South African exegetes in especially the earlier part of Phil Botha's career.

There was, however, not much depth in South African biblical scholarship's engagement with semiotics: the references may on occasion have extended to Roman Jakobson and Russian formalism, though without much analysis, and did not at all keep up with this burgeoning, and meta-theoretically useful, field - cf., e.g., John Deely, Basics of Semiotics (4 ${ }^{\text {th }}$ edition, Tartu: Tartu University Press, 2005) for an overview of the discipline of Semiotics.

8 Cf., e.g., Nissim Amzallag, "The Musical Mode of Writing of the Psalms and its Significance," OTE 27 (2014): 17-40. In such analyses, the phenomenological parallels between music and spirituality - on which, cf., e.g., Hetta Potgieter and Christo Lombaard, "Spiritualiteit en Musiek: Gevleuelde Dissiplines," Vir die Musiekleier 352 (2015): 9-24 - is indicated quite inadvertently by telling formulations such as "(t)he mysterious organization of the text of the psalms..." (Amzallag, "The Musical Mode," 29): music and faith seem phenomenologically to have a natural connection.

9 On music and interculturality, cf., e.g., Eva Fock, "Music - Intercultural Communication? Micro Musics, World Music and the Multicultural Discourse," Nordicom Information 4 (1997): 55-58.

10 For a broader study on music the world of the Hebrew Bible, cf. Theodore Burgh, Listening to the Artifacts. Music Culture in Ancient Palestine (London: T\&T Clark, 2006); Joachim Braun, Music in Ancient Israel/Palestine. Archaeological, Written, and Comparative Sources (Grand Rapids, MI: Eerdmans, 2002); Siobhán Long and John Sawyer, The Bible in Music. A Dictionary of Songs, Works, and More (Lanham, ML: Rowman \& Littlefield, 2015). 
known as is the case with modern music, the body of scholarship on these 150 canonised lyrics (and the non-canonised Psalms, the hymns in the rest of the Hebrew Bible, and music in the ancient Near East more generally) would have been constituted much differently. The demands made on scholars would have been greater too: our musical literacy would have had to be at least equal to our literacy in the Hebrew language and the conventions of Semitic poetry, and also our insights into the culture and history of the ancient Near East. As Van Dyk formulates this realisation: "The content of the songs sung by Israel are of course known to us from books like the Psalms, but in other respects our knowledge is very limited."11

However, even if we had abundant musical notation, in the manner we understand it, from the ancient world, this would not fully solve the problem of recouping such music: as noted, music notation is open to (performative) interpretation too, as much as any literary text is, even if not in identical ways. The italicisation of "in the manner we understand it" above, serves to indicate that I also hold to the criticism of a too Westernised rendition of the Hebrew Bible text as music by (amongst her other works) Haïk-Vantoura; ${ }^{12}$ this, despite a more positive recent assessment of this work of Haïk-Vantoura by Mitchell. ${ }^{13}$ However, the rendering of Psalm melodies (amongst others from the Hebrew Bible) as if they could as well have had been chanted in mediaeval monasteries, ${ }^{14}$ does not take seriously enough "der garstig breite Graben" between modern and ancient cultures, in the much-quoted terminology, and foundational 1777 insight, of Lessing. ${ }^{15}$ The assessment by Van Dyk, ${ }^{16}$ that even if there may be "a link between early Jewish and Gregorian music and even further back to biblical music ... this relationship is still unclear and shrouded in mystery. For this reason we do not know exactly what biblical music sounded like, or how it was performed," should in the light of the renewed prominence given by Mitchell ${ }^{17}$ to the work of Haïk-Vantoura ${ }^{18}$ be stated even more strongly. There is namely

\footnotetext{
11 Peet van Dyk, "Music in Old Testament Time," OTE 4 (1991): 373-380, 373.

12 Suzanne Haïk-Vantoura, La musique de la Bible revélée (Paris: Dessain et Tolra, 1978).

13 David C. Mitchell, "Resinging the Temple Psalmody," JSOT 36 (2012): 355-378.

14 As does openly, for instance, Hal H. Hopson, The Psalter: Psalms and Canticles for Singing (choir edition, Louisville, KY: Westminster John Knox Press, 2011), 5658. On the history of the tonus peregrinus, the typical Gregorian tonal chant, cf., e.g., Mattias Lundberg, Tonus Peregrinus: The History of a Psalm-tone and Its Use in Polyphonic Music (Farnham, NY: Ashgate, 2011).

15 Gotthold Ephraim Lessing, "Über den Beweis des Geistes und der Kraft," in Werke, 8. Bd.: Theologiekritische Schriften III, Philosophische Schriften (ed. Herbert Göpfert; München: Hanser, 1979 [1777]), 13.

16 Van Dyk, "Music in Old Testament Time," 373.

17 Mitchell, "Resinging the Temple Psalmody," 355-378.

18 Haïk-Vantoura, La musique de la Bible revélée.
} 
no likelihood that the music of the Old Testament world sounded like the music of the mediaeval monastery. The latter is Western; the former, earlier Semitic. To conflate these two musical idioms does create something new, but it does not recreate the biblical musical expression. Ancient Hebrew musicality is not thus authentically represented in this modern musicality, which remains a latter-day reimagination (which is positive!), but not a reconstruction (which would be expecting too much of a historiographical exercise). ${ }^{19}$

The musicality of the Psalms, rather, would have sounded much closer to the kind of music - almost non-music to modern ears - discussed already in the 1980 Biblical Archaeology Review (BAR) article, "World's Oldest Musical Notation Deciphered on Cuneiform Tablet" 20 on the so-called Ugaritic "Song Tablet":

The phenomenon and expression of music in Israel and Palestine ... reflected resemblances of their neighbouring environment. . . . Interaction between the particularities of these two worlds [of the Ancient Orient and Israel/Palestine] become evident ... cultic music in the Ancient Orient provided a socio-cultural space for the cultic music of Israel. $^{21}$

The fact that the excavated cuneiform tablet under discussion in this BAR publication contains a kind of overleaf heading with the words "This is a song...", already cements the nature of that text, and with the help of other texts from the wider frames of time and geography, the musical notation could be deciphered too. On a reconstructed ancient lyre, an experimental replaying of this Ugaritic "Song Tablet" could be attempted, recorded as "Sounds from Silence", ${ }^{22}$ which is available in the public domain. Though the song dates from

19 In this case too, the pastness of the past cannot be circumvented; history cannot be made alive again in the present - cf. Jurie le Roux, "The nature of historical understanding (or: hermeneutics and history)," Studia Historiae Ecclesiasticae 19 (1993): 35-63; even if Le Roux's point here was not intended to be related directly to musicality too.

20 Biblical Archaeology Review, "World's Oldest Musical Notation Deciphered on Cuneiform Tablet," BAR 6, no. 5 (1980): 14-19, 23-25. Resources such as this give access to a substantial body of scholarship on musicality across the ancient world: https://oi-idb.uchicago.edu/results.php?qb\%5Boperator\%5D

$\% 5 \mathrm{Bc} 3 \% 5 \mathrm{D}=\& \mathrm{qb} \% 5 \mathrm{Bdataset} \% 5 \mathrm{D} \% 5 \mathrm{Bc} \% 5 \mathrm{D}=\& \mathrm{qb} \% 5 \mathrm{Bfield} \% 5 \mathrm{D} \% 5 \mathrm{Bc} \% 5 \mathrm{D}=\& \mathrm{qb} \% 5 \mathrm{Bte}$ $\mathrm{rm} \% 5 \mathrm{D} \% 5 \mathrm{Bc} 3 \% 5 \mathrm{D}=$ music.

21 Cf. Dirk Human, "Cultic Music in the Ancient Orient and in Ancient Israel/Palestine," VF 56 (2011): 45-52.

22 Anne Kilmer and Richard Crocker, "Sounds from Silence" (CD recording, Berkeley, CA: Bit Enki Publications, 1974); more easily accessible online at https://archive.org/details/MC_1978_01_25. Cf. more generally, Theodore Burgh, Listening to the Artifacts. 
a few centuries to a full millennium older than the Psalter, ${ }^{23}$ this is still closer in time, geography and especially culture to the Psalms than the main seats of modern Bible scholarship are.

Despite this dearth in up-close insights into the ancient Semitic musicality of the Psalms, from the Psalms themselves it is clear that here, indeed, music is at play. This is evident as much from the titles ${ }^{24}$ as from the contents of various Psalms, not the least of which is the collection closing verses of Psalm 150:3$5: 25$

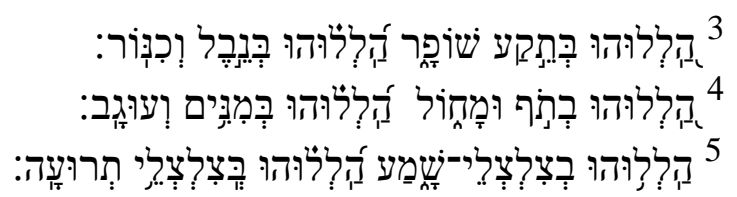

Already the repetition in the lyrics of these music verses give what may be termed fair warning that the attending music was "rather monotonous" too, most probably "characterised by the repetition of the same note, and two consecutive notes are seldom more than one whole step (note) apart..." Typically, an ancient Hebrew "song is composed of four notes, with three notes dominating". ${ }^{26}$ Latter-day tastes would with difficulty countenance such music, whether it be performed within religious or other settings. The reverse would naturally be as true.

\section{PSALMS NOW PLAYED}

Undoubtedly, the "scriptures of the Jewish and Christian canons have also stimulated a musical Wirkungsgeschichte from ancient times till today". ${ }^{27}$ The reinterpretation is such, however, that the sense of religious gravity was still maintained in Psalm renderings gathered in church hymnals ${ }^{28}$, meant to be accompanied by an often fittingly imposing church organ, and in the classical music genre. Of the latter, the De Profundis (which is based on the text of Psalm 130) compositions by JS Bach in the early 1700s (drawing heavily on Martin

\footnotetext{
23 Human, "Cultic Music in the Ancient Orient," 45.

24 Louis Jonker, "Another Look at the Psalm Headings: Observations on the Musical Terminology,” JNSL 30 (2004): 65-85.

25 E.g. Edo Škulj, "Musical Instruments in Psalm 150," in The Interpretation of the Bible. The International Symposium in Slovenia (JSOTSup 289; ed. Jože Krašovec; Sheffield: Sheffield Academic Press, 1999), 1117-1130.

26 Van Dyk, "Music in Old Testament Time," 376-377.

27 Human, "Cultic Music in the Ancient Orient," 52.

28 On which, cf., e.g., Elsabé Kloppers, "'n Nuwe Psalmomdigting in Afrikaans: Uitgangspunte, Beleid, Probleme," HTS 56 (2000): 192-204 and Cas Vos and Tom Gouws, "Op Hom die Groot Hosannas - Perspektiewe op die Bewaring en Vernuwing van die Kerklied,” SK 11 (1990): 209-221.
} 
Luther's rendering of this Psalm) ${ }^{29}$ and in 1980 (based on the Vulgate text) by the most performed living classical composer of our time Arvo Pärt, ${ }^{30}$ amongst others, provide exemplary instances. However, such solemnity had, by and large, disappeared once the Psalms had begun to be rendered overtly in the pop music genre. The recording of Psalms 19 and 137, conflated, in "By the rivers of Babylon," popularised largely ${ }^{31}$ as "Disco Psalm"32 by the group Boney-M in 1978, and ever since (even though nowadays mostly during the Christmas season), has become an unavoidable example. ${ }^{33}$

By the time the Psalms reach the era of modern electronic music, the break with the ancient is such that there is not much of a discernible attempt even to

29 Cf., e.g., Peter Williams, The Organ Music of J.S. Bach (2 $2^{\text {nd }}$ ed., Cambridge: Cambridge University Press, 2003), 422-424.

30 Cf. e.g. Andrew Shenton, Arvo Pärt's Resonant Texts: Choral and Organ Music 1956-2015 (Cambridge: Cambridge University Press, 2018), 78-79.

31 On the history of this song, cf. Steve Turner, Turn, Turn, Turn: Popular Songs Inspired by the Bible (Franklin, TN: Worthy Publishing, 2018), 59; more broadly, Max Stern, Psalms \& Music. Influences of the Psalms on Western Music (Brooklyn, NY: KTAV, 2013).

32 So memorably called by Parminder Summon, Summon's Bible Miscellany (Norwich: Canterbury Press, 2006), 6. When music and religion are considered academically, it is not the case that the bulk of presentations would only focus on for instance church organ pieces or on the religious dimensions of classical music (of which for instance Händel's Messiah, 1742, and Pergolesi's Stabat Mater, 1736, form indisputable cultural highlights in the history of the world). In the recent "Conference on Music and the Sacred" (held from 12 to 14 November 2018 in Helsinki, Finland; cf. https://musicandthesacred.com), for instance, the rock genre found its place too. The same is the case with chapters included in the relatively newly established Peter Lang book series "Music and Spirituality" (www.peterlang.com/view/serial/MAS; edited by June Boyce-Tillman, formerly of the Tavener Centre for Music and Spirituality at the University of Winchester in the UK), which has published eight volumes since its establishment in 2014.

33 At times the anthem-like status of a rock song could be such that it resembles what in the popular imaginary may well constitute something of a psalm-like position of societal resonance, leading to such valuations as: "I am quite confident in calling [the rock song] 'American Pie' a modern Psalm", made by Stephen Webb, "The Sound of Salvation. A Proposed Theology of Rock and Roll," First Things: A Monthly Journal of Religion \& Public Life 246 (2014): 41. Cf. Jacqueline Lapsley, "Bring on Your Wrecking Ball': Psalm 73 and Public Witness," ThTo 70 (2013): 62-68 and Olga Mikhelson, "Do You Believe in Rock'n'Roll? Popular Music as 'Religion'." Paper presented at the Religion - Continuations and Disruptions $17^{\text {th }}$ Annual Conference of the European Association for the Study of Religion (University of Tartu, Estonia, 2529 June 2019). 
recoup the ancient; the break with mainstream church music through the ages ${ }^{34}$ is equally clear. At most, only metaphorically a linkage with the Psalms are maintained. This can be found for instance in Krzysztof Penderecki's Psalmus $1961^{35}$ and in the response to it some half a century later, with Lionel Marchetti's PSALMUS (Omnis Spiritus Laudet Dominum), ${ }^{36}$ in which none of the mentioned traditions are recouped except for the referential titles of these two musical pieces.

Such less than direct taking up of the Psalms, the Bible, Judeo-Christian religious traditions and of matters of faith in general cannot be traced in full. ${ }^{37} \mathrm{It}$

34 The alternative, of purposively drawing on this tradition, is found in e.g. Martin Tel, Joyce Borger and John D. Witvliet, Psalms for All Seasons: A Complete Psalter for Worship (Grand Rapids, MI: Brazos, 2012).

35 Krzysztof Penderecki, "Psalmus 1961", taped: Stockholm, 10 April 1961 [cited 30 April 2019]. Online: https://ninateka.pl/kolekcje/en/three-composers/penderecki/audio /psalmus-1961.

36 Lionel Marchetti "PSALMUS (Omnis Spiritus Laudet Dominum) / 2013 composition de musique concrete," Polish Radio Experimental Studio [cited 30 April 2019]. Online: https://lionelmarchetti.bandcamp.com/album/psalmus-omnis-spirituslaudet-dominum-2013-composition-de-musique-concr-te.

37 The early origins of the Rock music genre can be traced to African American church music in the early 1900s, which exhibited a charismatic expression of Christianity. This created shared or in some respects parallel phenomenological heritages which can only be explained from this historical intersection. These shared phenomenological traits includes a sense for the experiential, in which individuals find themselves drawn into and taken up, even in some respects subsumed to, both the group involved and the medium of communication at once. The rock genre as a whole can however not be described as religious: the orientation towards matters of faith in this genre covers many possibilities, including thematics and symbolisms, quotations and allusions; appreciative, dismissive and conversions to and from.

Gospel rock, which often understands itself as an adaption not in the format of the rock genre, but in the lyrical content and associated lifestyle, is thus not in the first instance a conversion of a non-religious musical format into an evangelical communication tool. Rather, in broadest strokes, gospel rock (and from there, taking over one of the more extreme expressions of this genre, heavy metal music, as "Christian metal") is a re-adaptation of the initially Christian genre as a later highly popular secularised expression of music. We find this musical tradition thus, again in broad strokes, moving from its earliest African American church setting, into the broader American and from there Americanised international culture, again into religious format in its expression as Gospel rock.

The religious heritage of this secularised music genre had therefore never left the latter fully a-religious, as is often assumed, or anti-religious, of which rock music is often accused from within church circles. Although both these a- and anti-religious dimensions are certainly to be found in such a popular and widely supported genre as rock music, the situation is more nuanced that outright dismissal or a one-sided critical stance towards rock music could allow for. As could more naturally be expected of the 
has for instance been said of the most influential composer of rock music, Bob Dylan (notably awarded the 2016 Nobel Prize in literature) that his lyrics cannot be understood without having a good grasp of biblical literature, which he often includes in various creative, often implicit ways in his song lyrics; ${ }^{38}$ much the same can be said about other major singer-songwriters such as Leonard Cohen or, in South Africa, for instance, Koos Kombuis. Only a project of encyclopaedic proportions could attempt a substantive overview of this intersection of the indicated religious heritage in modern musical expressions. On another side of the spectrum, moreover, some rock groups understand themselves, and are widely understood to be ardently anti-religious in orientation, such as the most influential Afrikaans group over recent decades, called Fokofpolisiekar. However, the only slightly tongue-in-cheek evaluation on a consistently antireligious lyricism in almost all of their most popular songs perhaps remains valid: ${ }^{39}$

...there has, outside of Gospel music circles, never been a more religiously-inclined popular music band in Afrikaans, and perhaps in South African popular music in toto, than Fokofpolisiekar. Precisely the rejection of traditional Afrikaans religiosity and of aspects of faith in general in their music make this sustained theme palatable. With Fokofpolisiekar, God rocks.

most widely practiced and supported music genre in human history, shades of meaning abound for anyone given to taking a close look.

On the history of this genre, cf. e.g. Thomas Larson, History of Rock and Roll $\left(3^{\text {rd }}\right.$ ed.; Dubuque, IA: Kendall Hunt Publishing Company, 2012).

Within Afrikaans context, this musical heritage was received within a religious atmosphere in e.g. Francois Mulder, "Kontekstuele Prediking met behulp van Rockmusiek," in "...in die Wêreld..." Vyf Bydraes tot Kontekstuele Prediking (ed. Christo Lombaard, Christo; Johannesburg: Lewende Woorde / Dept. Greek \& Latin Studies, University of Johannesburg, 1999), 70-92.

Engaging in a deliberately playful misinterpretation game with the Psalms may relate directly to at least three rock music genres:

- Rock around the clock, Elvis Presley style: - Ps. 57:8 “Awake, my glory, awake, lyre and harp, that I may awake the dawn."

- Death metal in the Psalms - Ps. 137:9: "a blessing on anyone who seizes your babies and shatters them against a rock!"

- Protest music against a politician who has fallen out of favour - Ps. 109:8: "Let his days be few; let another take his office.")

38 Cf. e.g. Michael Gilmour, Tangled Up in the Bible: Bob Dylan \& Scripture (New York, NY: Continuum, 2004).

39 Christo Lombaard, “'Sing unto the LORD a New Song' (Ps. 98:1): Aspects of the Afrikaans Punk-Rock Group Fokofpolisiekar's Musical Spirituality as Rearticulated Aspects of the 1978 Afrikaans Psalm-en Gesangeboek," in Who is an African? Race, Identity, and Destiny in Post-Apartheid South Africa (eds Chammah Kaunda and Roderick Hewitt; Lanham, ML: Lexington Books / Fortress Academic), 209-222. 
Place this yet again over against the rock band U2, one of the most influential and long-standing music acts of all time, whose music is in adaptive versions of Christianity at times used in Eucharist services, then creatively named a "U2Charist". 40

The varieties of interaction between rock music and religion ancient and current seem from these possibilities to approach the immensity of the creative possibilities music itself allows for.

To summarise the above: the sense of the musical, in however an altered form, had therefore long been a part of the Judeo-Christian heritage of religious expression related to the Psalms, be that 1.) in liturgical recitals, 2.) in adapting the Psalms for use in hymnals intended for group use in congregations, 3.) in the use of Psalms in other religious music, 4.) through reference to the Psalms in non-religious music by means of allusions or quotations or - even if rarely (almost) full text renderings, and 5.) in explicit rejection that implies, still, some sort of connection, even fascination with religion (especially if set over against distanced indifference, which simply does not note the religious heritage).

It is on the fourth of these five possibilities that the emphasis will fall in the remainder of this contribution. In this case too, however, the established tradition within Psalm Studies rather than in the disciplines in Musicology is kept to that the lyrics take precedence to the musical aspects. This emphasis, not to imply that lyrics are neglected in Musicological disciplines; to the contrary, much can be learnt by Psalms scholars inclined to interdisciplinarity from how the words in musical compositions are treated by Musicologists.

\section{BONO MEETS THE PSALMS: ROCKIN' 'N' ROLLIN' CHRISTIAN SPIRITUALITY}

The U2 lead singer, rock musician Bono ${ }^{41}$ comes, for many unsuspectingly so, close to the topic here when he introduces his booklet on the Psalms by putting to words, unapologetically and in modern language, the problems related to the

40 See e.g. Kevin Donovan, "U2Charist to Hit England for the First Time," Christian Today (29 January 2007) [cited 12 July 2019]. Online: www.christiantoday.com/ article/u2charist.to.hit.england.for.the.first.time/9316.htm.

41 Bono, lead singer and songwriter of U2 and political activist, maintains a close involvement with the Psalms - see e.g. his pocket book on the Psalms, Bono, Selections from the Book of Psalms (New York, NY: Grove Press, 1999), vii-x and his 2016 documentary with Eugene Peterson, The Psalms (2016) [cited 12 July 2019; online: www.youtube.com/watch?v=-140S5e90KY. See also William Goodman, “Assured Lament': U2 Sing the Psalms," Relegere: Studies in Religion and Reception 2 (2012): 109-132 and Andrew Lewis, "Stravinsky and U2 Fix Psalm 40," Journal of Bible Reception 2 (2015): 69-85; more generally, William Goodman, Yearning for You: Psalms and the Song of Songs in Conversation with Rock and Worship Songs (Sheffield: Sheffield Phoenix, 2012). 
Bible. In an almost Mertonian moment, ${ }^{42}$ he then includes reference to the Psalm 22:1 text ("My God, my God, why have you forsaken me?"), alluding to Jesus, though without reading Psalm 22 Christologically (that is, based on this Psalm 22 verse taken up in Mark 15:34 as one of the Jesus words on the cross, with Matthew 27:46 following Mark in this) as is often done in non-exegetical contexts; that unwonted text by Bono ${ }^{43}$ is quoted here in full:

Explaining belief has always been difficult. How do you explain a love and logic at the heart of the universe when the world is so out of kilter with this? Has free will got us crucified? And what about the dodgy characters who inhabit the tome known as the Bible, who hear the voice of God?

You have to be interested, but is God?

Explaining faith is impossible: vision over visibility; instinct over intellect. A songwriter plays a chord with the faith that he will hear the next one in his head.

One of the writers of the psalms was a musician, a harp-player whose talents were required at "the palace" as the only medicine that would still the demons of the moody and insecure King Saul of Israel. It is a thought that still inspires: Marilyn sang for Kennedy, the Spice Girls for Prince Charles.

At the age of 12, I was a fan of David. He felt familiar, like a pop star could feel familiar. The words of the psalms were as poetic as they were religious, and he was a star. Before David could fulfil the prophecy and become the king of Israel, he had to take quite a beating. He was forced into exile and ended up in a cave in some no-name border town facing the collapse of his ego and abandonment by God. But this is where the soap opera got interesting. This is where David was said to have composed his first psalm -- a blues. That's what a lot of the psalms feel like to me, the blues. Man shouting at God - "My God, my God, why hast thou forsaken me? Why art thou so far from helping me?" (Psalm 22).

I hear echoes of this holy row when un-holy bluesman Robert Johnson howls, "There's a hellhound on my trail" or Van Morrison sings, "Sometimes, I feel like a motherless child." Texas Alexander mimics the psalms in "Justice Blues": "I cried Lord my father, Lord kingdom come. Send me back my woman, then thy will be done." Humorous, sometimes blasphemous, the blues was backslidin' music but, by its very opposition, it flattered the subject of its perfect cousin, gospel.

42 Cf. Thomas Merton, Bread in the Wilderness (London: Burns and Oates, 1953) and Thomas Merton, Praying the Psalms (Collegeville, PA: The Order of St. Benedict, 1956).

43 Bono, Selections from the Book of Psalms (New York, NY: Grove Press, 1999), 1. 
Abandonment and displacement are the stuff of my favourite psalms. The Psalter may be a font of gospel music, but for me it's despair that the psalmist really reveals and the nature of his special relationship with God. Honesty, even to the point of anger. "How long, Lord? Wilt thou hide thyself forever?" (Psalm 89), or "Answer me when I call" (Psalm 5).

Psalms and hymns were my first taste of inspirational music. I liked the words, but I wasn't sure about the tunes -- with the exception of Psalm 23, "The Lord is my Shepherd." I remember them as droned and chanted rather than sung. But they prepared me for the honesty of John Lennon, the baroque language of Bob Dylan and Leonard Cohen, the open throat of Al Green and Stevie Wonder. When I hear these singers, I am reconnected to a part of me I have no explanation for -- my "soul" I guess.

Words and music did for me what solid, even rigorous, religious argument could never do -- they introduced me to God, not belief in God, more an experiential sense of GOD. Over art, literature, girls, my mates, the way in to my spirit was a combination of words and music. As a result, the Book of Psalms always felt open to me and led me to the poetry of Ecclesiastes, the Song of Solomon, the book of John... My religion could not be fiction, but it had to transcend facts. It could be mystical, but not mythical.

My mother was Protestant, my father Catholic. Anywhere other than Ireland that would be unremarkable. The "Prods" at that time had the better tunes and the Catholics had the better stage-gear. My mate Gavin Friday used to say: "Roman Catholicism is the Glamrock of religion" with its candles and psychedelic colours -- cardinal blues, scarlets and purples -- smoke bombs of incense and the ring of the little bell. The Prods were better at the bigger bells, they could afford them. In Ireland, wealth and Protestantism went together. To have either was to have collaborated with the enemy -- that is, Britain. This did not fly in our house.

After going to Mass at the top of the hill, in Finglas on the north side of Dublin, my father waited outside the little Church of Ireland chapel at the bottom of the hill, where my mother had brought her two sons.

I kept myself awake thinking of the clergyman's daughter and let my eyes dive into the cinema of the stained glass. These Christian artists had invented the movies. Light projected through colour to tell their story. In the Seventies the story was "the Troubles," and the Troubles came through the stained glass, with rocks thrown more in mischief than in anger. But the message was the same: the country was to be divided along sectarian lines. I had a foot in both camps, so my Goliath became religion itself: I began to see religion as the perversion of faith. I began to see God everywhere else. In girls, fun, 
music, justice and still -- despite the lofty King James translation -the Scriptures.

I loved these stories for the basest reasons. These were action movies, with some hardcore men and women, the car chases, the casualties, the blood and guts. There was very little kissing.

David was a star, the Elvis of the Bible, if we can believe the chiselling of Michelangelo. And unusually for such a "rock star," with his lust for power, lust for women, lust for life, he had the humility of one who knew his gift worked harder than he ever would. He even danced naked in front of his troops -- the biblical equivalent of the royal walkabout. David was definitely more performance artist than politician.

Anyway, I stopped going to churches and got into a different kind of religion. Don't laugh. That's what being in a rock 'n' roll band is. Showbiz is shamanism, music is worship. Whether it's worship of women or their designer, the world or its destroyer, whether it comes from that ancient place we call soul or simply the spinal cortex, whether the prayers are on fire with a dumb rage or dove-like desire, the smoke goes upwards, to God or something you replace God with -- usually yourself.

Years ago, lost for words and with 40 minutes of recording time left before the end of our studio time, we were still looking for a song to close our third album, War. We wanted to put something explicitly spiritual on the record to balance the politics and romance of it; like Bob Marley or Marvin Gaye would. We thought about the psalms -Psalm 40. There was some squirming. We were a very "white" rock group, and such plundering of the scriptures was taboo for a white rock group unless it was in the "service of Satan". Psalm 40 is interesting in that it suggests a time in which grace will replace karma, and love will replace the very strict laws of Moses (in other words, fulfil them). I love that thought. David, who committed some of the most selfish as well as selfless acts, was depending on it. That the scriptures are brim full of hustlers, murderers, cowards, adulterers and mercenaries used to shock me. Now it is a source of great comfort.

" 40 " became the closing song at U2 shows, and on hundreds of occasions, literally hundreds of thousands of people of every size and shape of T-shirt have shouted back the refrain, pinched from Psalm 6: "How long (to sing this song)." I had thought of it as a nagging question, pulling at the hem of an invisible deity whose presence we glimpse only when we act in love. How long hunger? How long hatred? How long until creation grows up and the chaos of its precocious, hell-bent adolescence has been discarded? I thought it odd that the vocalising of such questions could bring such comfort -to me, too. 
But to get back to David, it is not clear how many of these psalms David or his son Solomon really wrote. Some scholars suggest that the royals never dampened their nibs and that there was a host of Holy Ghost writers. Who cares? I didn't buy Leiber and Stoller -- they were just his songwriters. I bought Elvis.

Here we find, in one of the most articulate rock music voices of our time, the Psalms, music and spirituality together brought to life in a different way than could be done by academic exegetes or would be done in church life, for the most part. The booklet:

- Explains the author's own journey of faith.

- It does so without giving way to the temptations not to face the difficulties brought by/within the Bible and Christianity and without eschewing the natural and the unusual aspects of growing up.

- It does so in interaction with the musical influences that formed his particular spirituality.

- The writing is artistic and clever, with word and image play that would attract readers both from his already committed fan base and from outside this group.

- The Psalms in particular colour as much the text here as do the other influences, combined with humour and pathos, and with honest estimations of the value of church as much as rock music.

- The experience of life-and-faith, of a life of faith stands at the forefront with "experience" 44 being also the key term up to the latest music release by US, titled Songs of experience (2017).

The last paragraph in the booklet quoted above could be counted as a sermon of sorts, a life lesson, perhaps, as much as the initial parts could be instructive for its intended readership. However, that closing paragraph has perhaps more to say to exegetes than the rest of that text. This "more to say", not as final answer, or as an accusation, but ought rather be taken as an encouragement for us to do more, to reflect deeper, to read more widely, to perform (write and talk) more popularly, to engage across disciplines. Exegetes are part of the speech choir that performs the score set by the music of the ages in the Psalms themselves.

44 The most recent offering on diversity of religious experiences related to music is June Boyce-Tillman, Stephen Roberts and Erricker, Jane, eds., Enlivening Faith: Music, Spirituality and Christian Theology (Bern: Peter Lang, 2019). 


\section{E CONSIDERING TOGETHER THE PSALMS' ANCIENT MUSICALITY, LATER MUSICAL RECEPTION AND BONO'S PSALMIC SPIRITUALITY}

As exegetes, we do not have the historical resources with which to reconstruct the musicality of the Psalms of the Hebrew Bible with any sufficient degree of plausibility. This musicality is nevertheless accepted as a given, attested to as it is by the texts of the Psalms themselves as much as by the genre of the Psalms as lyrical poetry. This fissure in scholarship has however proven to be creative, allowing for artistic interpretations throughout the centuries to fill imaginatively what is historically unavailable. All of these artistic renditions relay to their intended audiences, by means of the interpretative strengths and limitations of the composers concerned, a current (be that in e.g. the 1700s or in 2017) musical window on the Psalms concerned. When one of those composers, both current to our time and influential in numerically large musical and religious circles, namely in the person of the band U2's Bono, reflects artfully on the Psalms, music and spirituality, that becomes important for exegetes too. The text by Bono relayed above, is a resource of great value for any exegete interested in how our work communicates, or could potentially communicate, outside the smaller academic and church circles in which we typically serve. We may not be able to hear how the Psalms were sung in the ancient world, but in engaging meaningfully with such modern musical reflections, we may indeed assist the world in our time in making the Psalms, still, sing.

\section{BIBLIOGRAPHY}

Amzallag, Nissim. "The Musical Mode of Writing of the Psalms and its Significance." Old Testament Essays 27 (2014): 17-40.

Biblical Archaeology Review. "World's Oldest Musical Notation Deciphered on Cuneiform Tablet." Biblical Archaeology Review 6/5 (1980): 14-19, 23-25.

Bono and Eugene Peterson. The Psalms (2016) [cited 12 July 2019). Online: www.youtube.com/watch?v=-140S5e90KY.

Bono, Selections from the Book of Psalms. Pocket Canons. New York, NY: Grove Press, 1999.

Boyce-Tillman, June, Stephen Roberts and Jane Erricker. Eds. Enlivening Faith: Music, Spirituality and Christian Theology. Bern: Peter Lang, 2019.

Braun, Joachim. Music in Ancient Israel/Palestine. Archaeological, Written, and Comparative Sources. Grand Rapids, MI: Eerdmans, 2002.

Burgh, Theodore. Listening to the Artifacts. Music Culture in Ancient Palestine. London: T\&T Clark, 2006.

Childs, Brevard. Old Testament Theology in a Canonical Context. London: SCM, 1985.

Deely, John. Basics of Semiotics. $4^{\text {th }}$ ed. Tartu: Tartu University Press, 2005.

Deist, Ferdinand. Witnesses to the Old Testament. Literature of the Old Testament 5. Pretoria: NG Kerkboekhandel, 1988.

Donovan, Kevin. "U2Charist to Hit England for the First Time." Christian Today (29 January 2007) [cited 29 July 2019]. Online: www.christiantoday.com/article /u2charist.to.hit.england.for.the.first.time/9316.htm. 
Fock, Eva. "Music - Intercultural communication? Micro musics, world music and the multicultural discourse." Nordicom Information 4 (1997): 55-65.

Gillingham, Susan. Psalms through the Centuries. Volume Two. Oxford: Wiley Blackwell, 2018.

Gilmour, Michael. Tangled Up in the Bible: Bob Dylan \& Scripture. New York, NY: Continuum, 2004.

Goodman, William. "'Assured Lament': U2 Sing the Psalms." Relegere: Studies in Religion and Reception 2 (2012): 109-132. https://doi.org/10.11157/rsrr2-1-483.

Goodman, William. Yearning for You: Psalms and the Song of Songs in Conversation with Rock and Worship Songs. Sheffield: Sheffield Phoenix, 2012.

Haïk-Vantoura, Suzanne. La musique de la Bible revélée. Paris: Dessain et Tolra, 1978.

Hopson, Hal H. The Psalter: Psalms and Canticles for Singing. Choir edition. Louisville, KY: Westminster John Knox Press, 2011.

Human, Dirk. "Cultic Music in the Ancient Orient and in Ancient Israel/Palestine." Verkündigung und Forschung 56 (2011): 45-52. https://doi.org/10.14315/vf-2011 -56-2-45.

Jonker, Louis. "Another Look at the Psalm Headings: Observations on the Musical Terminology." Journal of North-West Semitic Languages 30 (2004): 65-85.

Kloppers, Elsabé. "'n Nuwe Psalmomdigting in Afrikaans: uitgangspunte, beleid, probleme." Hervormde Teologiese Studies 56 (2000): 192-204. https://doi.org/10. 4102/hts.v56i1.1707.

Kilmer, Anne and Richard Crocker. "Sounds from Silence". CD recording. Berkeley, CA: Bit Enki Publications, 1974.

Lapsley, Jacqueline. "“Bring on Your Wrecking Ball': Psalm 73 and Public Witness." Theology Today 70 (2013): 62-68. https://doi.org/10.1177/0040573612473142.

Larson, Thomas. History of Rock and Roll. $3^{\text {rd }}$ edition. Dubuque, IA: Kendall Hunt, 2012.

Le Roux, Jurie. "The nature of historical understanding (or: hermeneutics and history)." Studia Historiae Ecclesiasticae 19 (1993): 35-63.

Lessing, Gotthold Ephraim. "Über den Beweis des Geistes und der Kraft.” Pages 9-14 in Werke, 8. Bd.: Theologiekritische Schriften III, Philosophische Schriften. Edited by Herbert Göpfert, München: Hanser, 1979 [1777]. https://doi.org/ 10.1515/9783111408620-003.

Lewis, Andrew Z. "Stravinsky and U2 Fix Psalm 40." Journal of Bible Reception 2 (2015): 69-85. https://doi.org/10.1515/jbr-2015-0004.

Lombaard, Christo, "'Sing unto the LORD a New Song' (Ps. 98:1): Aspects of the Afrikaans Punk-rock Group Fokofpolisiekar's Musical Spirituality as Rearticulated Aspects of the 1978 Afrikaans Psalm- en Gesangeboek." Pages 209-22 in Who is an African? Race, Identity, and Destiny in Post-Apartheid South Africa. Edited by Chammah Kaunda and Roderick Hewitt, Lanham, ML: Lexington Books / Minneapolis, MN: Fortress Academic, 2018.

Long, Siobhán and John Swayer. The Bible in Music. A Dictionary of Songs, Works, and More. Lanham, ML: Rowman \& Littlefield, 2015.

Lundberg, Mattias. Tonus Peregrinus: The History of a Psalm-tone and Its Use in Polyphonic Music. Farnham: Ashgate, 2011. https://doi.org/10.4324/9781315550 $\underline{848}$.

Martin Tel, Joyce Borger and John D. Witvliet. Psalms for All Seasons: A Complete Psalter for Worship. Grand Rapids, MI: Brazos, 2012. 
Merton, Thomas. Praying the Psalms. Collegeville, KY: The Order of St. Benedict, 1956.

Merton, Thomas. Bread in the Wilderness. London: Burns and Oates, 1953.

Mikhelson, Olga. "Do You Believe in Rock'n'Roll? Popular Music as 'Religion'." Paper presented at the Religion - Continuations and Disruptions $17^{\text {th }}$ Annual Conference of the European Association for the Study of Religion, University of Tartu, 25-29 June 2019.

Mitchell, David C. "Resinging the Temple Psalmody." Journal for the Study of the Old Testament 36 (2012): 355-378. https://doi.org/10.1177/0309089212437995.

Mulder, Francois. “Kontekstuele prediking met behulp van rock-musiek." Pages 70-92 in "...in die Wêreld..." Vyf Bydraes tot Kontekstuele Prediking. Johannesburg: Lewende Woorde / Dept. Greek \& Latin Studies, University of Johannesburg, 1999.

Potgieter, Hetta and Christo Lombaard. "Spiritualiteit en Musiek: Gevleuelde Dissiplines." Vir die Musiekleier 35 (2015): 9-24.

Shenton, Andrew. Arvo Pärt's Resonant Texts: Choral and Organ Music 1956-2015. Cambridge: Cambridge University Press, 2018. https://doi.org/10.1017/97811 $\underline{39998345 .}$.

Summon, Parminder. Summon's Bible Miscellany. Norwich: Canterbury Press, 2006.

Škulj, Edo. "Musical Instruments in Psalm 150." Pages 1117-1130 in The Interpretation of the Bible. The International Symposium in Slovenia. Journal for the Study of the Old Testament Supplements 289. Edited by Jože Krašovec. Sheffield: Sheffield Academic, 1999.

Stern Max, Psalms \& Music. Influences of the Psalms on Western Music. Brooklyn, NY: KTAV, 2013.

Thiselton, Anthony. New Horizons in Hermeneutics. Grand Rapids: Zondervan, 1992.

Turner, Steve. Turn, Turn, Turn: Popular Songs Inspired by the Bible. Franklin, TN: Worthy Publishing, 2018.

Van Dyk, Peet. "Music in Old Testament Time." Old Testament Essays 4 (1991): 373380.

Vos, Cas and Tom Gouws. "Op Hom die Groot Hosannas - Perspektiewe op die Bewaring en Vernuwing van die Kerklied." Skrif en Kerk 11 (1990): 209-221. https://doi.org/10.4102/ve.v11i2.1022.

Webb, Stephen. "The Sound of Salvation. A Proposed Theology of Rock and Roll," First Things: A Monthly Journal of Religion \& Public Life 246 (2014): 41-45.

Williams, Peter. The Organ Music of J.S. Bach. $2^{\text {nd }}$ Edition. Cambridge: Cambridge University Press, 2003.

Prof Christo Lombaard, Department of Christian Spirituality, Church History and Missiology, UNISA, South Africa, Email: lombacjs@unisa.ac.za. ORCID: https://orcid.org/0000-0003-0019-4717. 